\title{
Aphid migrant activity in refuge habitats of the Wielkopolska agricultural landscape
}

\author{
Barbara Wilkaniec ${ }^{1 *}$, Beata Borowiak-Sobkowiak ${ }^{1}$, Agnieszka Wilkaniec ${ }^{2}$, \\ Wojciech Kubasik ${ }^{1}$, Maria Kozłowska ${ }^{3}$, Ewa Dolańska-Niedbała ${ }^{1}$
}

Poznań University of Life Sciences, Dąbrowskiego 159, 60-594 Poznań, Poland

${ }^{1}$ Department of Entomology and Environmental Protection

${ }^{2}$ Department of Landscape Architecture

${ }^{3}$ Department of Mathematical and Statistical Methods

Received: September 10, 2014

Accepted: February 11, 2015

\begin{abstract}
Refuge habitats have a stabilising effect on the entomofauna in the agricultural landscape. The objective of this research was to follow the migrant activity of aphids in two types of refuge habitats: shrubs and roadsides of rural areas. Moericke traps method were used for testing the seasonal activity of aphids. The dynamics of species numbers were assessed, and the phenology of the dominating taxa was examined. From 2008 to 2010, more than 5,000 winged aphids from 94 species were caught in shrub habitats, and 83 species were caught in rural roadside habitats. The characteristics of aphid groups were defined on the basis of selected indicators. Annually, in both locations, flight activity was shown by a group of several taxa. The rank position of the species was varied in the particular sites and years of the research. Species participation differed when analysing aphid flights, so the seasons were divided into three separate periods: spring, summer, and autumn.
\end{abstract}

Key words: aphids, biocenotic indices, phenology, roadside, shrubs

\section{Introduction}

An increased intensity of agricultural practices in the last decades has caused such environmental problems as contamination, soil degradation, and biodiversity losses (Tilman et al. 2002). Former varied and complex landscapes with well-balanced proportions of arable land, grassland, forests, fallows, hedgerows, and other semi-natural habitats have been transformed into homogeneous, simple landscapes with a domination of arable land. These changes are related to the local loss of diversity and ecological functioning (Pickett and Cadenasso 1995; Roland and Taylor 1997; Thies and Tscharntke 1999; Tischendorf and Fahring 2000; Menalled et al. 2001; Thieset al. 2003).

Agricultural landscape structure, which includes the configuration and the composition of crop and non-crop habitats, affect entomofauna movement, abundance, and diversity. Forests, meadows, hedgerows, and field margins all provide resources and habitat connectivity for different arthropod groups. It is commonly predicted that pest regulation will be greater in landscapes that contain a greater proportion or diversity of these habitats (Bianchi et al. 2006; Chaplin-Kramer et al. 2011). We lack a detailed understanding of how different components of landscape structure influence insect herbivores, their predators and parasites, the spatial scales at which this occurs, and the effects on crop production (Chaplin-Kramer et al. 2011).
Non-crop habitats provide alternative hosts or preys, pollen, nectar, and overwintering sites (Lethmayer 1998; Dennis et al. 2000; Martin et al. 2013) and favorable environmental conditions for many arthropod species (Bianchi et al. 2006).

Landscape structure effects operate at different scales for different arthropod groups depending on the mobility and size of the groups (Tscharntke and Brandl 2004). Many authors argue that to enhance ecosystem services what is needed are pollination or pest biological control by effective habitat management (Tscharnke et al. 2007; Martin et al. 2013).

Studies about annual crops show that complex landscapes dominated by non-crop habitats can lead to higher predator densities (Gardiner et al. 2009) or lower abundance of pestsin crop fields (Thies and Tscharntke 1999; Östman et al. 2001; Thies et al. 2005; Gardiner et al. 2009). Several studies, conducted in Poland, have examined the different effects of the elements of landscape on beneficial entomofauna; in particular the parasitoids and predators (Bońkowska 1970; Sawoniewicz 1979; Dąbrowska-Prot 1991; Gałecka 1991; Twardowski et al. 2006; Wojciechowicz-Żytko 2009; Wojciechowicz-Żytko and Wnuk 2009; Piekarska-Boniecka et al. 2010) as well as pollinating insects (Banaszak 2000). 
However, studies on the effect of landscape composition and habitat isolation on biological control of pests on tree crops, are scarce. Nevertheless, recent studies found that biological control of pest insects on tree crops is influenced by landscape composition (Brown 2004; Eilers and Klein 2009; Dib et al. 2010; Thomson and Hoffmann 2010; Stutz and Entling 2011).

It is very important to known the time periods which insects exploit particular landscape elements. This a crucial aspect of any recommendations for the enhancement of ecosystem services by landscape management.

Aphids are a major pest on a wide range of crops and trees. Adults and larvae of different coccinellid species, larvae of syrphids, chrysopids, and cecidomyiids, and parasitoids, are expected to reduce the population growth of aphids on fruit trees (Brown 2004; Dib et al. 2010).

Here we investigated the aphid species composition, abundance, and the phenology of dominating taxa in two non-crop habitats, in the vicinity of apple orchards. In these habitats aphids can be dealt as a potential and alternative food base for all the above-mentioned predators and parasitoids.

The objective of this research was to follow the migrant activity of aphids in two types of refuge habitats in the agricultural landscape of Wielkopolska. The two refuge habitats were: shrubs (S) and roadsides (R). Both habitats were situated near apple orchards. In the studied environments, the species composition and the dynamics of species numbers were assessed, and the phenology of dominating taxa was examined.

Migrant activity of aphids has been widely perceived as a phenomenon of dispersal in search of a host plant. Migration concerns both seasonal flights, undertaken by heteroecious species for the sake of an obligatory change of the host plant (in spring, from the primary host to the secondary host, and in autumn the reverse - from the secondary to the primary host), and flights undertaken in search for other plants belonging to the same host species. This phenomenon is encountered in mono- and heteroecious taxa, and is connected mainly with the nutrient quality and the effect of a large density of specimens in colonies. Aphid seasonal flights can be accurately followed by means of Moericke traps which catch winged morphs of insects. This method was applied to track aphids in the present research.

\section{Materials and Methods}

The research was carried out on two sites, shrubs (S) $\left(52^{\circ} 10^{\prime} 10^{\prime \prime} \mathrm{N}\right.$; $\left.16^{\circ} 81^{\prime} 19^{\prime \prime} \mathrm{E}\right)$ and by the roadside (R) $\left(52^{\circ} 10^{\prime} 20^{\prime \prime} \mathrm{N}\right.$; $\left.16^{\circ} 81^{\prime} 45^{\prime \prime} \mathrm{E}\right)$ in the rural area of Gorzyczki in the Kościan district, $40 \mathrm{~km}$ south of Poznań, from 2008 to 2010. Aphids were caught using circular Moericke traps. The traps had a diameter of $18 \mathrm{~cm}$ and a height of $11 \mathrm{~cm}$. An aqueous of ethylene glycol and a detergent were used to catch the aphids. The traps were placed at a height of $1.5 \mathrm{~m}$. Ten traps were used at each site and in each growth season, from May until October. Traps were located about $2 \mathrm{~m}$ from the edge of each habitat and the distance between the traps was $10 \mathrm{~m}$ within the habitat. Every 10 days, the traps were emptied. After the aphids were taken out of the traps, the aphids were stored in tubes in $75 \%$ ethyl alcohol. The material was identified using the keys by Taylor (1984) and by Blackman and Eastop (1994).

Shrub habitat, situated on the edge of a 5 ha apple orchard, constituted a $200 \mathrm{~m}$ long and $8 \mathrm{~m}$ wide stretch of a plant complex which was spatially diversified and comprised shrub phytocenoses: Euonymo-Prunetum spinosae and forest phytocenoses in the form of a fragment of Querco-Ulmetum minoris as well as herbal communities. At this location, trees were comprised of eight different species (Ulmus laevis, Quercus robur, Fraxinus excelsior, Acer platanoides, Acer negundo, Malus domestica, Salix alba, Populus $\times$ canadensis) with maple ash being the most popular. In the dense layer of shrubs, Crataegus monogyna dominated, and among the diversified herb plants - the nettle (Urtica dioica) and the thistle (Cirsium arvense) dominated. The site located by the roadside was situated near a 3-ha-large apple orchard. Tree composition was characterised by a multi-species floral composition where walnut (Juglans regia) dominated together with many maple trees, oaks, elms, and ash. Shrubs were more diverse ( $\mathrm{Cra}$ taegus $\times$ media, C. monogyna, Rosa canina, Sambucus nigra, Corylusavellana, Cornus alba, Euonymus europea, Symphoricarpus albus, Sarothamnus scoparius, Ribes niveum, Prunus spinosa) which were characteristic of the Rhamno-Prunetea class where Crataegus $\times$ media dominated as well as herbs, predominantly: U. dioica, Poapratensis, Lolium perenne, Equisetum arvense, and Galium aparine.

When analysing the changeability of atmospheric conditions during the course of the research, it was found that all seasons were relatively warm. Over the period of the study, the year 2008 was the warmest, and 2010 the coldest. As far as the total rainfall was concerned, all years were very humid, while 2010 had the most abundant rainfall (Table 1).

On the basis of selected indicators, the following characteristics of aphid groups were defined:

- number of samples $(n)$,

- number of individuals $(N)$,

- dominance index $(D)$ (dominance is the percentage of specimens of particular species in the community), and the following dominance classes were adopted [according to Durak and Wojciechowski (2008)]: eudominant - over $20 \%$ of the collected material, dominant $-10-20 \%$ of the collected material, subdominant $-5-10 \%$ of the collected material, recedent $-1-5 \%$ of the collected material, subrecedent - less than $1 \%$ of collected material;

- index of general species diversity, as defined by Shannon-Weaver (1963) $\left(H^{\prime}\right)$ :

$$
H^{\prime}=-\sum_{i=1}^{S} \frac{n_{i}}{N} \log _{2} \frac{n_{i}}{N}
$$

where: $n_{\mathrm{i}}$ - number of individuals (i) of the species in the grouping of general number of individuals $(N)$, $S$ - number of species in the community; 
Table 1. Average monthly air temperatures and monthly rainfalls for the Research Station in Turew from 2008 to 2010

\begin{tabular}{|c|c|c|c|c|c|c|c|c|}
\hline \multirow[b]{2}{*}{ Months } & \multirow{2}{*}{$\begin{array}{c}\text { Temp. } \\
{\left[{ }^{\circ} \mathrm{C}\right]} \\
2008\end{array}$} & \multirow{2}{*}{$\begin{array}{c}\text { Rainfall } \\
{[\mathrm{mm}]} \\
2008\end{array}$} & \multirow{2}{*}{$\begin{array}{c}\text { Temp. } \\
{\left[{ }^{\circ} \mathrm{C}\right]} \\
2009\end{array}$} & \multirow{2}{*}{$\begin{array}{c}\text { Rainfall } \\
\text { [mm] } \\
2009\end{array}$} & \multirow{2}{*}{$\begin{array}{c}\text { Temp. } \\
{\left[{ }^{\circ} \mathrm{C}\right]} \\
2010\end{array}$} & \multirow{2}{*}{$\begin{array}{c}\text { Rainfall } \\
\text { [mm] } \\
2010\end{array}$} & \multicolumn{2}{|c|}{ Long-term average 1971-2000 } \\
\hline & & & & & & & $\begin{array}{c}\text { monthly temp. } \\
{\left[{ }^{\circ} \mathrm{C}\right]}\end{array}$ & $\begin{array}{c}\text { monthly rainfall } \\
{[\mathrm{mm}]}\end{array}$ \\
\hline I & 2.8 & 59 & -2.5 & 13 & -6.1 & 0 & -0.9 & 37.3 \\
\hline II & 4.6 & 28 & 0.3 & 26 & -0.2 & 13 & 0.1 & 28.2 \\
\hline III & 5.0 & 48 & 4.8 & 51 & 4.5 & 53 & 3.9 & 39.0 \\
\hline IV & 10.0 & 85 & 13.3 & 31 & 10.6 & 27 & 8.6 & 39.7 \\
\hline $\mathrm{V}$ & 15.8 & 17 & 14.6 & 93 & 12.7 & 100 & 14.3 & 50.0 \\
\hline VI & 20.2 & 18 & 16.6 & 83 & 18.7 & 47 & 17.3 & 72.1 \\
\hline VII & 19.7 & 77 & 20.1 & 130 & 22.2 & 164 & 19.1 & 88.4 \\
\hline VIII & 19.5 & 184 & 20.0 & 56 & 19.3 & 244 & 18.7 & 68.2 \\
\hline IX & 13.8 & 27 & 16.1 & 103 & 12.9 & 157 & 14.1 & 44.8 \\
\hline$x$ & 10.0 & 66 & 7.9 & 103 & 7.1 & 6 & 9.2 & 38.8 \\
\hline XI & 5.9 & 27 & 7.0 & 49 & 6.3 & 96 & 3.7 & 41.4 \\
\hline XII & 1.8 & 19 & -0.3 & 27 & -6.2 & 36 & 0.2 & 40.0 \\
\hline Annual total & - & 655 & - & 765 & - & 943 & - & 587.9 \\
\hline $\begin{array}{l}\text { Annual } \\
\text { average }\end{array}$ & 10.8 & - & 9.8 & - & 8.5 & - & 9 & - \\
\hline
\end{tabular}

- indicator of evenness of Pielou's index of species frequency(1966) $\left(J^{\prime}\right)$ :

$$
J^{\prime}=\frac{H^{\prime}}{H_{\max }}=\frac{H^{\prime}}{\log _{2} N^{\prime}}
$$

- indicator of species richness as defined by Simpson (1949) $(d)$ :

$$
d=\frac{S-1}{\log N} \times 100 \%
$$

For comparing the structure of the aphid groups, Marczewski-Steinhouse's indicator (1959) (MS) was applied in quality categories:

$$
M S=\frac{c}{a+b-c} \times 100 \%,
$$

where: $a$ and $b$-number of species in the first and second community, respectively, $c$ - number of species common to both compared communities.

While in quality-quantity categories, Hutcheson's test (1970) was applied. The data was statistically analysed using Stat-Soft, Inc. (2010) Statistica, version 9.0.

\section{Results}

From 2008 to 2010, there were 5,154 aphid winged individuals from 94 species caught in the shrub habitat located in the rural region of Gorzyczki. Similarly, in the roadside habitat, 3,820 specimens and 83 species were caught (Table 2).

The seasonal dynamics of the activity of winged aphid individuals was consistent for all the seasons studied throughout the research period. This is expressed both in the number of specimens and species caught, and is characterised by two clear peaks in numbers dur- ing spring and autumn, and a decline in summer, usually lasting from the second decade of July until the second decade of September. The increased intensity of aphid flights in spring and autumn can be easily explained by the phenomenon of mass migration of heteroecious species associated with changing the host plant. The greatest numbers of winged morphs were collected in the shrub habitat during the autumn peaks of 2009 and 2010, with up to 600 individuals/10 traps/decade. Correspondingly, by the roadside, fewer morphs were observed, i.e. up to 300 individuals/10 traps/decade (Fig. 1). During these same periods in the season, i.e. spring and autumn, the maximum diversity of aphid species were recorded. The richest composition of aphid species recorded at both sites was during the spring, when 23 species/10 traps/decade were recorded in the shrub habitat, while in the 2009 season - up to 30 species/10 traps/decade were recorded by the roadside (Fig. 2).

Each year, at both locations, extensive flight activity was shown by a group of approximately thirteen taxa, including the most numerous Rhopalosiphum padi. Over the three seasons of the research project, $R$. padi constituted $62.4 \%$, in total, in the shrub habitat. At the roadside location, this taxon comprised $64.7 \%$ of all collected winged morphs. The following species occupied the remaining positions in this category: Phorodon humuli (5.6\%) and Anoecia corni (4.3\%). The next five consecutive taxa characteristically represented $1-5 \%$ of all the collected winged aphids in the season: Aphis fabae, A. sambuci, Myzus persicae, Sitobion avenae, and Acyrthosiphon pisum (Table 3).

The rank position of taxa continued to vary over the particular sites and years of the research project. In the shrub habitat, R. padi was eudominant in 2009 and 2010, amounting to 76.9 and $57.2 \%$ of the total aphid catch, respectively. In the first research year, this species was dominant within the group together with Periphyllus testudinaceus and P. humuli. The class of subdominants for 2008 was comprised of Drepanosiphum platanoidis and 
Table 2. List of aphid species and their number in shrubs and roadside localities collected using Moericke traps in Gorzyczki from 2008 to 2010

\begin{tabular}{|c|c|c|c|c|c|c|}
\hline \multirow{3}{*}{ Aphid species } & \multicolumn{6}{|c|}{ Number of aphids in locality } \\
\hline & \multicolumn{3}{|c|}{ shrubs } & \multicolumn{3}{|c|}{ roadside } \\
\hline & 2008 & 2009 & 2010 & 2008 & 2009 & 2010 \\
\hline Acyrthosiphum pisum (Harris) & 12 & 6 & 2 & 43 & 11 & 1 \\
\hline Adelges sp. & 3 & 3 & 3 & 4 & 1 & - \\
\hline Amphorophora gei (Börn.) & 5 & - & - & 1 & - & - \\
\hline A. rubi (Kalt.) & 5 & - & 2 & 2 & 2 & - \\
\hline Anoecia corni (F.) & 51 & 67 & 18 & 75 & 48 & 41 \\
\hline Aphis fabae Scop. & 58 & 63 & 39 & 27 & 24 & 39 \\
\hline A. pomi De Geer & 3 & 8 & 5 & 1 & 3 & 2 \\
\hline A. sambuci L. & 72 & 45 & 23 & 38 & 10 & 6 \\
\hline Aphis spp. & 32 & 17 & 7 & 36 & 2 & - \\
\hline Atheroides serrulatus Hal. & 1 & - & - & - & - & - \\
\hline Aulacorthum solani (Kalt.) & - & 2 & - & - & 2 & - \\
\hline Betulaphis quadrituberculata (Kalt.) & - & - & 1 & - & - & - \\
\hline Brachycaudus cardui (L.) & - & 9 & 2 & - & 1 & - \\
\hline B. divaricatae Shap. & 14 & 22 & 5 & 11 & 10 & - \\
\hline B. helichrysi (Kalt.) & 3 & - & 1 & 4 & - & 1 \\
\hline B. linariae Stroyan & 1 & - & - & - & - & - \\
\hline Brachycaudus sp. & 25 & - & - & 15 & - & - \\
\hline B. schwartzi (Börn.) & - & - & 1 & - & - & 1 \\
\hline Brevicoryne brassicae (L.) & 4 & 2 & - & 6 & - & - \\
\hline Calaphis betulicola Szeleg. & 1 & - & - & 2 & - & - \\
\hline Callipteriniella tuberculata (Heyd.) & - & - & 1 & - & - & - \\
\hline Capitophorus elaeagni (Del Gu.) & 2 & 3 & 2 & - & - & - \\
\hline C. similis V.D. Goot & - & 1 & - & - & 1 & - \\
\hline Cavariella aegopodii (Scop.) & 48 & - & - & 52 & 1 & - \\
\hline C. konoi Takah. & 1 & - & - & 1 & - & - \\
\hline C. pastinaceae (L.) & 1 & - & - & - & - & - \\
\hline C. theobaldi (Gill. et Bragg) & 31 & - & 1 & 23 & - & - \\
\hline Ceruraphis eriophori (Walk.) & 3 & 1 & - & 2 & - & - \\
\hline Chaitophorus leucomelas Koch & 3 & 1 & 1 & 3 & 7 & \\
\hline Ch. populeti (Panz.) & - & - & 8 & - & - & 1 \\
\hline Ch. populialbae (B. de F.) & 1 & - & - & 1 & - & - \\
\hline Ch. salicti (Schrk.) & - & 1 & - & - & - & - \\
\hline Cinara sp. & - & 1 & 1 & 5 & - & - \\
\hline Corylobium avellana (Schrk.) & - & - & - & - & 1 & - \\
\hline Cryptomyzus galeopsidis (Kalt.) & 1 & 1 & - & 3 & - & 1 \\
\hline C. korschelti Börn. & - & - & 1 & - & - & - \\
\hline Drepanosiphum platanoidis (Schrk.) & 123 & 1 & 22 & 39 & - & 17 \\
\hline Dysaphis crataegi (Kalt.) & 2 & 4 & 1 & 3 & - & - \\
\hline D. plantaginea (Pass.) & 1 & 3 & 1 & 2 & 1 & 1 \\
\hline Eriosoma ulmi (L.) & 5 & - & 4 & 3 & 1 & - \\
\hline Eucallipterus tiliae (L.) & 5 & - & - & 3 & - & - \\
\hline Euceraphis betulae (Koch) & 7 & - & 20 & 9 & - & 6 \\
\hline Eulachnus agilis (Kalt.) & - & - & 1 & - & - & - \\
\hline Eulachnus sp. & 1 & - & - & - & - & - \\
\hline Forda formicaria Heyd. & 2 & - & 1 & & 1 & - \\
\hline Holcaphis sp. & 1 & - & - & 2 & - & - \\
\hline Hyadaphis foeniculi (Pass.) & - & - & - & 1 & - & - \\
\hline Hyalopterus pruni (Geoff.) & 1 & 6 & 3 & 18 & 7 & 1 \\
\hline Hypertomyzus lactucae (L.) & - & 17 & 2 & 5 & 7 & 1 \\
\hline H. lampsanae (Börn.) & 1 & - & - & - & - & - \\
\hline H. pallidus H.R.L. & - & 4 & 1 & 1 & & \\
\hline Impatietientinum asiaticum Nevsky & 1 & 1 & - & - & - & - \\
\hline Liosomaphis berberidis (Kalt.) & 1 & - & - & - & - & - \\
\hline Lipaphis erysimi (Kalt.) & - & 6 & - & 2 & 4 & - \\
\hline Macrosiphoniella artemisiae (B de F.) & - & - & - & & 2 & - \\
\hline M. tanacetaria (Kalt.) & - & 3 & - & 2 & 1 & - \\
\hline Macrosiphum euphorbiae (Thom.) & 5 & 1 & - & - & 3 & - \\
\hline M. funestum (Macch.) & - & - & - & - & 1 & - \\
\hline M. gei (Koch) & 1 & - & - & - & - & - \\
\hline M. persequens (Walk.) & - & - & - & 1 & - & - \\
\hline M. rosae (L.) & - & - & 1 & 10 & 2 & 1 \\
\hline Macrosiphum sp. & - & - & - & - & 1 & - \\
\hline Megoura viciae Buckt. & - & 1 & 1 & - & - & - \\
\hline Metopolophium dirhodum (Walk.) & 26 & 6 & 1 & 65 & 5 & \\
\hline Microlophium carnosum (Buckt.) & 1 & 24 & - & 36 & 18 & 1 \\
\hline Mimeuria ulmiphila (Del Gu.) & - & 2 & - & - & - & - \\
\hline Myzus cerasi (F.) & 5 & 3 & 2 & 12 & 1 & 2 \\
\hline
\end{tabular}


Table 2. List of aphid species and their number in shrubs and roadside localities collected using Moericke traps in Gorzyczki from 2008 to 2010 - continuation

\begin{tabular}{|c|c|c|c|c|c|c|}
\hline \multirow{3}{*}{ Aphid species } & \multicolumn{6}{|c|}{ Number of aphids in locality } \\
\hline & \multicolumn{3}{|c|}{ shrubs } & \multicolumn{3}{|c|}{ roadside } \\
\hline & 2008 & 2009 & 2010 & 2008 & 2009 & 2010 \\
\hline M. ligustri Mosl. & 1 & - & 1 & 2 & - & - \\
\hline M. lythri (Schrk.) & 1 & - & - & - & - & - \\
\hline M. persicae (Sulz.) & 10 & 72 & 2 & 30 & 16 & 17 \\
\hline Nasonovia ribisnigri (Mosl.) & - & 1 & - & - & - & - \\
\hline Ovatus crataegarius (Walk.) & 2 & 1 & - & - & 3 & - \\
\hline O. insitus (Walk.) & 1 & 1 & - & - & - & - \\
\hline Panaphis juglandis (Goetze) & & - & - & 82 & - & - \\
\hline Pemphigus sp. & 4 & - & 1 & 18 & - & - \\
\hline Periphyllus acericola (Walk.) & 1 & 1 & - & 14 & - & - \\
\hline P. aceris (L.) & & & 2 & - & - & - \\
\hline P. coracinus (Koch) & 2 & - & - & - & - & - \\
\hline P. hirticornis (Walk.) & 2 & - & - & - & - & - \\
\hline P. lyropictus (Kessl.) & - & - & - & 2 & - & - \\
\hline P. testudinaceus (Fern.) & 290 & 2 & 5 & 44 & 1 & - \\
\hline Phorodon humuli (Schrk.) & 263 & 1 & 23 & 73 & 1 & 28 \\
\hline Phyllaphis fagi (L.) & 1 & 1 & 1 & 3 & 1 & \\
\hline Phylloxera sp. & - & - & 1 & - & - & - \\
\hline Prociphillus bumeliae (Schrk.) & 1 & - & & - & - & - \\
\hline Pterocallis alni (De Geer) & 4 & - & 1 & 5 & - & - \\
\hline Pterocomma pilosum Buckt. & 2 & - & - & - & - & - \\
\hline P. populeum (Kalt.) & 5 & - & - & 2 & - & - \\
\hline$P$. rufipes Börn. & - & - & - & - & 1 & - \\
\hline Rhopalomyzus lonicerae (Sieb.) & - & - & - & 1 & - & - \\
\hline Rhopalosiphoninus latysiphon (David.) & 1 & - & - & - & 1 & - \\
\hline Rhopalosiphum insertum (Walk.) & 2 & 1 & 1 & 4 & - & 1 \\
\hline R. nymphaeae (L.) & - & - & 1 & - & 1 & - \\
\hline R. padi (L.) & 278 & 1,683 & 1,253 & 480 & 662 & 1,329 \\
\hline Sipha maidis Pass. & 1 & - & - & - & - & - \\
\hline Sitobion fragariae (Walk.) & - & 32 & - & - & 1 & - \\
\hline S. avenae (F.) & 11 & 42 & 3 & 43 & 23 & 2 \\
\hline Subsaltusaphis sp. & - & - & - & 1 & - & - \\
\hline Symydobius oblongus (Heyd.) & - & - & 1 & 1 & 1 & - \\
\hline Tetraneura ulmi (L.) & 5 & 14 & 17 & 6 & 10 & 13 \\
\hline Thelaxes dryophila (Schrk.) & 1 & - & - & 3 & - & - \\
\hline Therioaphis luteola (Börn.) & - & - & - & 1 & - & - \\
\hline T. riehmi (Börn.) & - & - & - & 1 & - & - \\
\hline T. trifolii (Mon.) & - & - & - & 4 & 1 & - \\
\hline Tinocallis platani (Kalt.) & 3 & - & - & 6 & & - \\
\hline Trama rara (Mordv.) & - & - & 2 & - & 1 & - \\
\hline Uroleucon (Uromelan) sp. & - & 2 & 1 & - & 2 & 1 \\
\hline Uromelan sp. & & & 2 & 3 & 1 & 1 \\
\hline Number of individuals/year & 1,462 & 2,189 & 1,503 & 1,398 & 907 & 1515 \\
\hline Number of individuals/3 years & - & 5,154 & - & - & 3,820 & - \\
\hline Number of species/year & 67 & 47 & 52 & 63 & 48 & 25 \\
\hline Number of species/3 years & - & 94 & - & - & 83 & - \\
\hline
\end{tabular}

A. sambuci. In the 2009 and 2010 seasons, none of these species maintained the same high position within the group structure (Table 4). Groups comprising seven taxa constituted recedents in the three seasons of the research project. Subrecedents in the three research years, consisted of groups of seven taxa each. The group of subrecedents was most numerously represented in the first research season by 55 species, and in the remaining seasons by 39 and 40 , respectively.

At the roadside, $R$. padi was eudominant in the aphid groups for all three seasons of the research project. Within the aphid groups, A. corni, Panaphis juglandis, and P. humuli were all subdominant. In 2009, A. corni held the same position (Table 4). The group of recedents was also large: in 2008, there were 12 taxa, and in the subsequent years, seven and six, respectively. The subrecedents group was comprised of 48,39 , and 18 species, respectively.
Species participation differed when analysing aphid flights dividing seasons into three separate periods: spring, summer, and autumn. In the spring of all three years, the greatest activity was recorded in the shrubs by: P. humuli (19.2\%), P. testudinaceus $(19 \%)$, D. plantanoidis (9.5\%), and A. sambuci (8.5\%). The most active species at the roadside location were: $P$. humuli $(7.9 \%), P$. juglandis $(7.7 \%)$, S. avenae $(6.3 \%)$, Microlophium carnosum $(5.4 \%)$, and Cavariella aegopodii (5.2\%) (Table 5). Other aphid species dominated in autumnal catches. In both refuge habitats, R. padi was certainly the most numerous species, constituting a total of $88.9 \%$ of all winged morphs recorded in the shrubs and $85 \%$ by the roadside for the three years of the research project. A high rank position was also occupied by $A$. corni, with $4 \%$ and $8.3 \%$, respectively. Subsequent positions were taken by M. persicae and A. fabae (Table 6). 

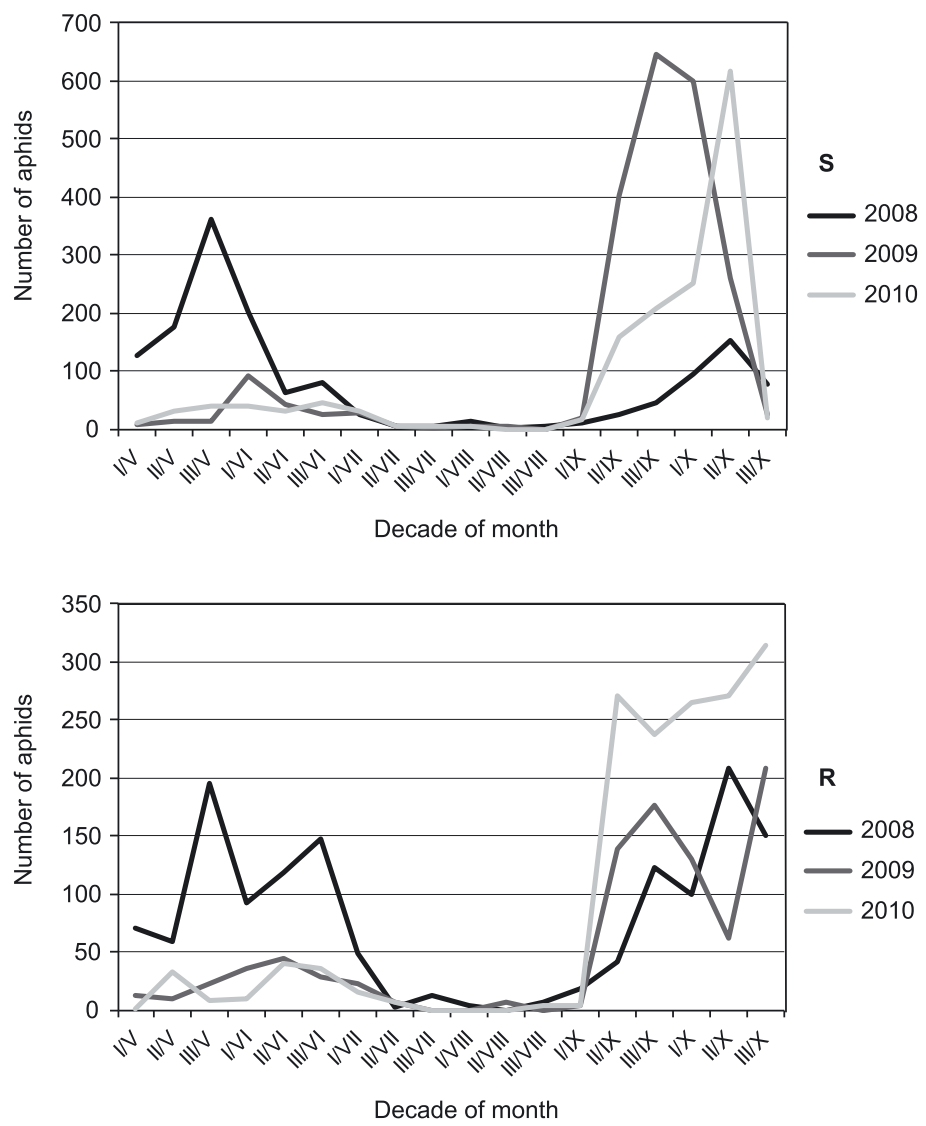

Fig. 1. Numerical changes of aphids in two sites, shrubs (S) and roadside (R) habitats in Gorzyczki in 2008-2010
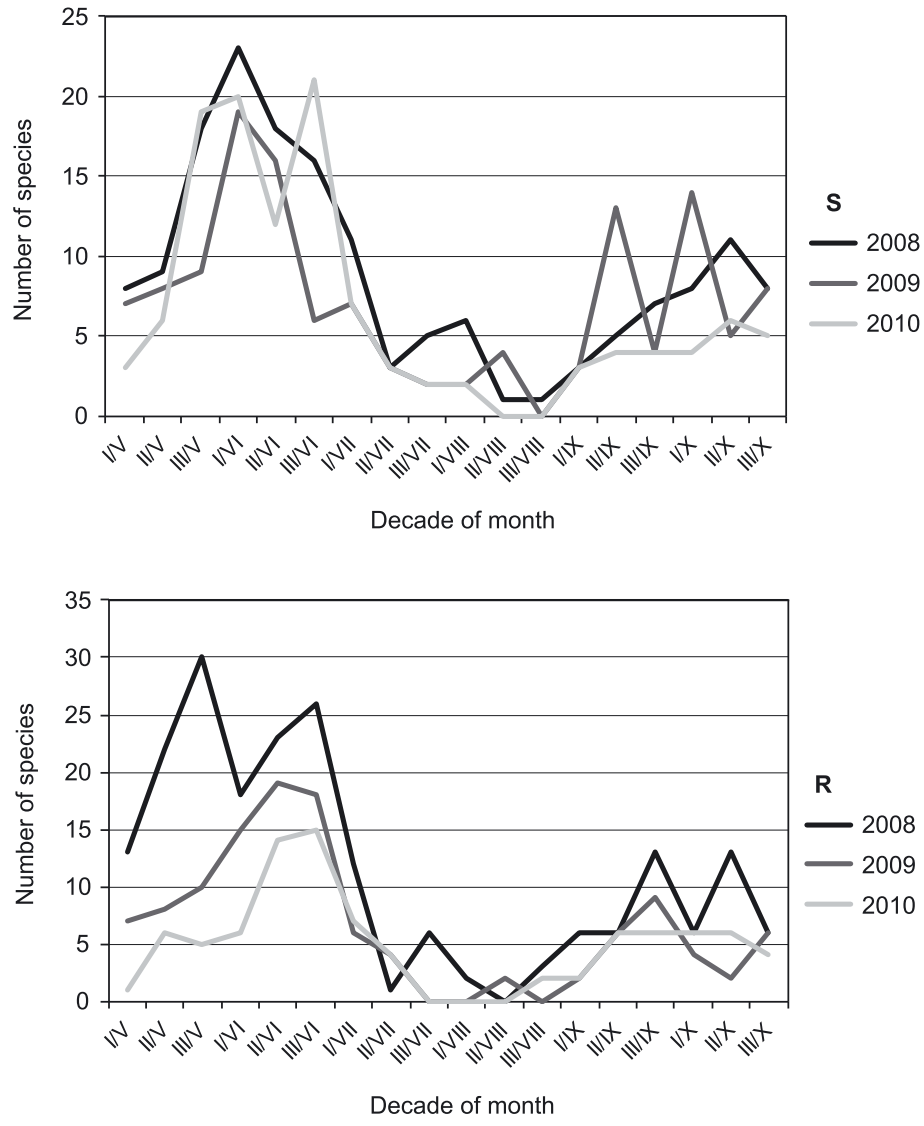

Fig. 2. Number of aphid species caught in two sites, shrubs (S) and roadside (R) habitats in Gorzyczki in 2008-2010 
Table 3. Aphid species caught in large numbers and annually using Moericke traps in refuge habitats in Gorzyczki during the 2008-2010 time period

\begin{tabular}{|c|c|c|c|c|}
\hline \multirow{2}{*}{ Species } & \multicolumn{2}{|c|}{ Shrubs } & \multicolumn{2}{|c|}{ Roadside } \\
\hline & number & $\%$ & number & $\%$ \\
\hline Rhopalosiphum padi & 3,214 & 62.4 & 2,471 & 64.7 \\
\hline Phorodon humuli & 287 & 5.6 & 102 & 2.7 \\
\hline Aphis fabae & 160 & 3.1 & 90 & 2.4 \\
\hline A. sambuci & 140 & 2.7 & 54 & 1.4 \\
\hline Anoecia corni & 136 & 2.6 & 164 & 4.3 \\
\hline Myzus persicae & 84 & 1.6 & 63 & 1.6 \\
\hline Sitobion avenae & 56 & 1.1 & 68 & 1.8 \\
\hline Acyrthosiphum pisum & 20 & 0.4 & 55 & 1.4 \\
\hline
\end{tabular}

Table 4. Abundance of aphid species in refuge habitats in Gorzyczki in the 2008-2010 time period

\begin{tabular}{|c|c|c|c|c|c|c|}
\hline \multirow[t]{2}{*}{ Species } & \multicolumn{3}{|c|}{$\begin{array}{c}\text { Shrubs } \\
\text { dominance index [\%] }\end{array}$} & \multicolumn{3}{|c|}{$\begin{array}{c}\text { Roadside } \\
\text { dominance index [\%] }\end{array}$} \\
\hline & 2008 & 2009 & 2010 & 2008 & 2009 & 2010 \\
\hline Rhopalosiphum padi & 19.0 & 76.8 & 57.2 & 34.3 & 72.9 & 87.7 \\
\hline Anoecia corni & 3.5 & 3.1 & - & 5.4 & 5.3 & 2.7 \\
\hline Aphis fabae & 4.0 & 2.9 & 1.8 & 1.9 & 2.6 & 2.6 \\
\hline A. sambuci & 4.9 & 2.1 & 1.1 & 2.7 & 1.1 & - \\
\hline Phorodon humuli & 18.0 & - & 1.1 & 5.2 & - & 1.8 \\
\hline Microlophium carnosum & - & - & - & 2.6 & 1.9 & - \\
\hline Cavariella aegopodii & 3.3 & - & - & 3.7 & - & - \\
\hline Drepanosiphum platanoidis & 8.4 & - & 1.0 & 2.8 & - & - \\
\hline Metopolophium dirhodum & - & - & - & 4.6 & - & - \\
\hline Periphyllus testudinaceus & 19.8 & - & - & 3.1 & - & - \\
\hline Sitobion avenae & - & - & - & 3.0 & 2.5 & - \\
\hline Panaphis juglandis & - & - & - & 5.9 & - & - \\
\hline Acyrthosiphum pisum & - & - & - & 31.0 & - & - \\
\hline Myzus persicae & 0.7 & 3.3 & - & 2.1 & 1.8 & - \\
\hline
\end{tabular}

Table 5. Aphid species caught in large numbers in spring in refuge habitats in Gorzyczki during the 2008-2010 time period

\begin{tabular}{lcccc}
\hline \multirow{2}{*}{ Species } & \multicolumn{2}{c}{ Shrubs } & \multicolumn{2}{c}{ Roadside } \\
\cline { 2 - 5 } & number & $\%$ & number & $\%$ \\
\hline Phorodon humuli & 287 & 19.2 & 81 & 4.9 \\
Periphyllus testudinaceus & 285 & 19.0 & 43 & 4.2 \\
Drepanosiphum platanoidis & 142 & 9.5 & 48 & 4.7 \\
Aphis sambuci & 128 & 8.5 & 48 & 4.7 \\
Rhopalosiphum padi & 70 & 4.7 & 42 & 4.6 \\
A. fabae & 66 & 4.4 & 53 & 5.2 \\
Cavariella aegopodii & 45 & 3.0 & 21 & 2.0 \\
Brachycaudus divaricatae & 41 & 2.7 & 65 & 6.3 \\
Sitobion avenae & 32 & 2.1 & 23 & 2.2 \\
C. theobaldi & 31 & 2.1 & 44 & 4.3 \\
Metopolophium dirhodum & 28 & 1.9 & 15 & 1.5 \\
Euceraphis betulae & 27 & 1.8 & 55 & 5.4 \\
Microlophium carnosum & 23 & 1.5 & 79 & 7.7 \\
Panaphis juglandis & 0 & 0 & & \\
\hline
\end{tabular}

Table 6. Aphid species caught in large numbers in autumn in refuge habitats in Gorzyczki during the 2008-2010 time period

\begin{tabular}{lrrrr}
\hline \multirow{2}{*}{ Species } & \multicolumn{2}{c}{ Shrubs } & \multicolumn{2}{c}{ Roadside } \\
\cline { 2 - 5 } & number & $\%$ & number & $\%$ \\
\hline Rhopalosiphum padi & 3,119 & 88.9 & 2,314 & 85.0 \\
Anoecia corni & 137 & 4.0 & 225 & 8.3 \\
Myzus persicae & 62 & 1.8 & 49 & 1.8 \\
Aphis fabae & 56 & 1.6 & 23 & 0.8 \\
Acyrthosiphon pisum & 11 & 0.3 & 37 & 1.6 \\
\hline
\end{tabular}


A

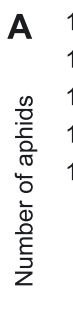

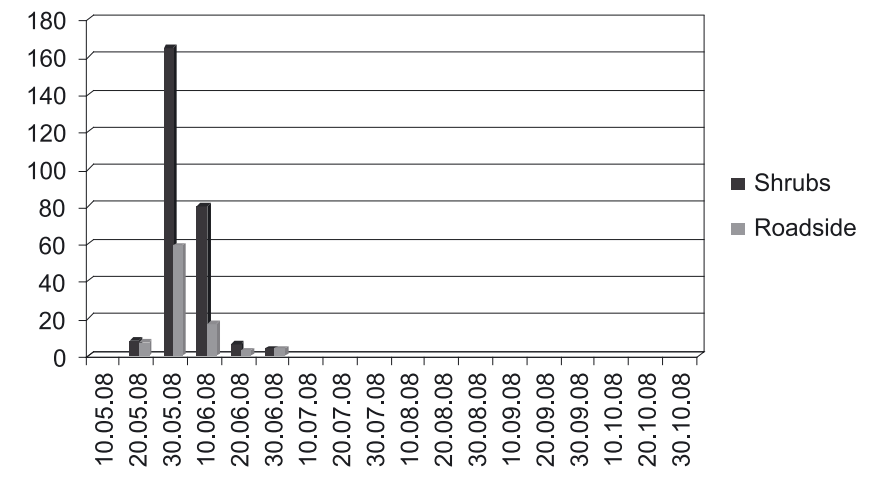

Decade of month

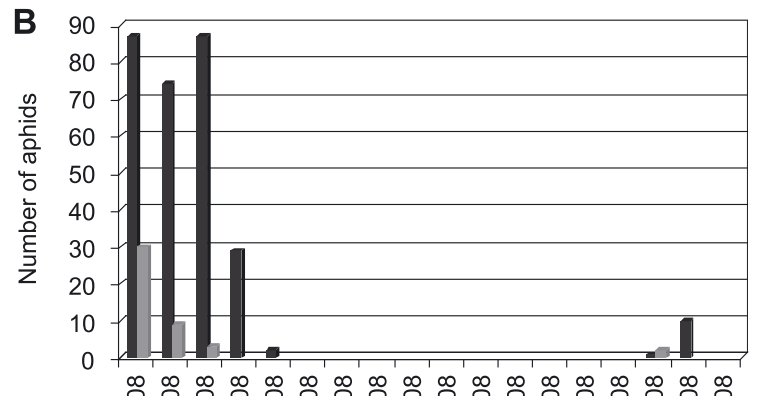

\% 崖

Decade of month

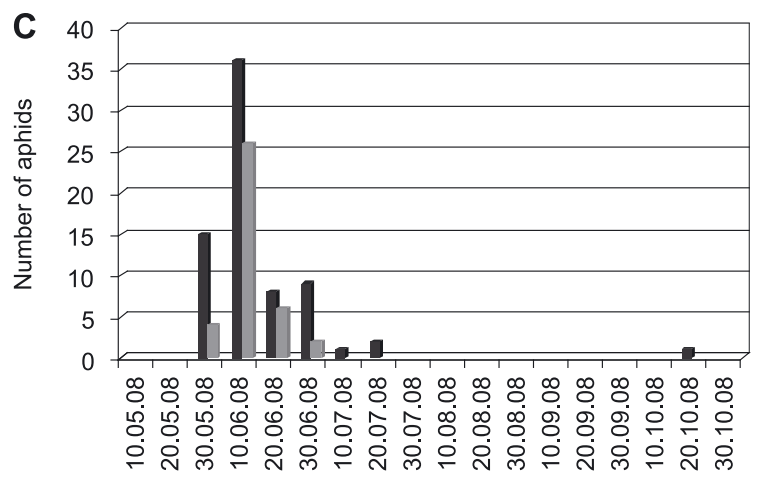

- Shrubs

Roadside

- Shrubs

Roadside

Decade of month

Fig. 3. Phenology of Phorodon humuli (A), Periphyllus testudinaceus (B), and Aphis sambuci (C) in shrubs and roadside habitats in Gorzyczki in 2008

Particular taxa differed when it came tothe phenology of the appearance of the winged individuals in a season. The flights of $P$. humuli, P. testudinaceus, and A. sambuci were particularly active in spring (Fig. 3). Yet in autumn, the most active were $R$. padi and A. corni (Fig. 4). The flights of $A$. fabae were highly active throughout the entire season (Fig. 4).

The comparison of the refuge habitats of the different aphid groups during particular research years, showedthat habitats differed significantly. The habitats differed in terms of general species diversity, as expressed by the $H^{\prime}$ coefficient but these did not differ between the years of the study (Table 7). In 2008, the highest species diversity expressed by the Shannon-Weaver index was recorded at the roadside and the shrub locations as 4.12 and 3.74, respectively. The lowest was recorded in both locations in 2010 as 1.40 and 0.95 , respectively. The same relations were recorded between groups compared on the basis of two subsequently calculated indices: Pielou's uniformity of species frequency $\left(J^{\prime}\right)$ and Simpson's species diversity (d) (Table 7).

Hutcheson's test was applied both quantitatively and qualitatively to compare the aphid communities in refuge habitats, shrubs, and roadside. The differences between them were proven statistically on the basis of the Shannon-Weaver formula (Table 7).

A comparison of the groups in terms of quality using the Marczewski-Steinhaus index, showed that the shrub habitat groups had between 30 to 33 common species. The similarity of species ranged from 38.37 to $43.48 \%$. The 


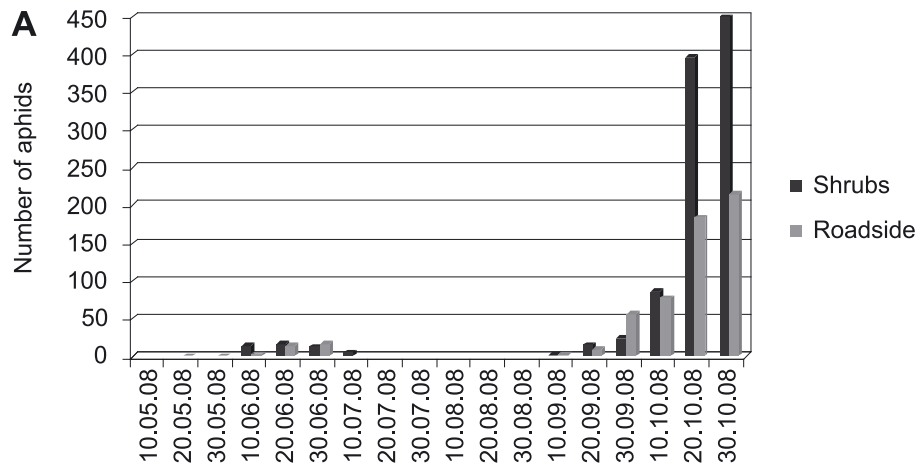

Decade of month

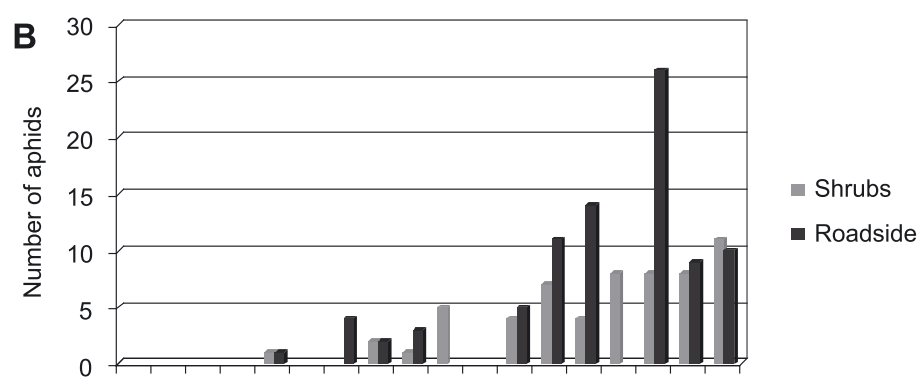

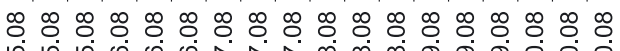

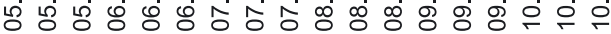

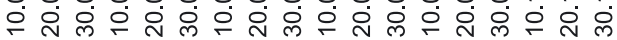

Decade of month

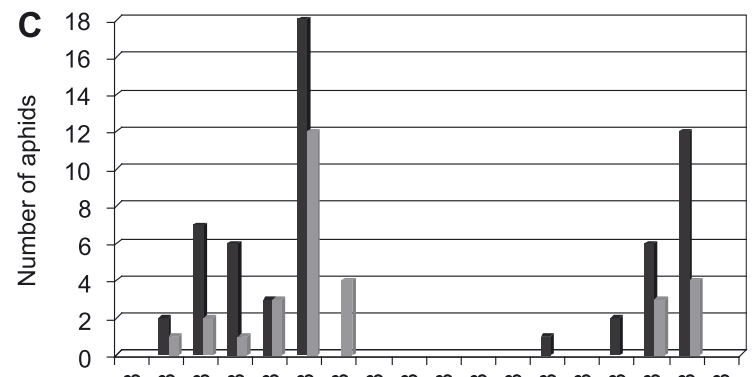

- Shrubs

Roadside

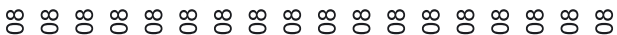

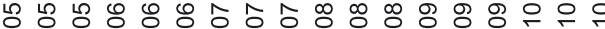

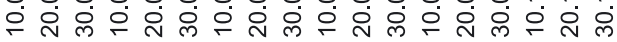

Decade of month

Fig. 4. Phenology of Rhopalosiphum padi (A), Anoecia corni (B), and Aphis fabae (C) in shrubs and roadside habitats in Gorzyczki in 2008

Table 7. Biocenotic indices from 2008-2010, characterising aphid communities at particular refuge habitats in Gorzyczki

\begin{tabular}{|c|c|c|c|c|c|c|}
\hline Refuge habitat & Year & $\begin{array}{c}\text { Number of } \\
\text { species }\end{array}$ & $\begin{array}{l}\text { Number of } \\
\text { individuals }\end{array}$ & $H^{\prime}$ & $J^{\prime}$ & $d$ \\
\hline \multirow[t]{3}{*}{ Shrubs } & 2008 & 67 & 1,462 & $3.74^{*}$ & 0.62 & 20.85 \\
\hline & 2009 & 47 & 2,189 & $1.75^{*}$ & 0.32 & 13.77 \\
\hline & 2010 & 52 & 1,503 & $1.40^{*}$ & 0.25 & 16.05 \\
\hline \multirow[t]{3}{*}{ Roadside } & 2008 & 64 & 1,398 & $4.12^{*}$ & 0.69 & 20.03 \\
\hline & 2009 & 48 & 907 & $2.03^{*}$ & 0.36 & 15.89 \\
\hline & 2010 & 25 & 1,515 & $0.95^{*}$ & 0.20 & 7.55 \\
\hline
\end{tabular}

*significance level of difference between values (t-test) $\alpha=0.05 ; H^{\prime}-$ Shannon Weaver index; $J^{\prime}-$ Pielou's index; $d$-Simpson index 
number of common species by the roadside was more diverse and the degree of similarity during the years of the study was smaller, ranging between 32.73 and $38.27 \%$. In the 2008 season, a comparison of the two groups settled in the shrubs and by the road, indicated that their similarity was high; reaching $55.97 \%$ and 47 common species.

\section{Discussion}

The large-scale activity of winged aphids in the researched refuge habitats in the agricultural landscape of Wielkopolska points to a wealth of aphid fauna. The presence of 94 and 83 aphid species or groups of aphid species, respectively, was recorded within the winged aphid groups, in shrubs, and by the roadside. The method applied, allows for the gathering of an abundant amount of material but does involve certain difficulties when interpretingthe research results. This stems from the fact, that winged aphid specimens from neighbouring habitats could also be found in the yellow dishes. Taking the above information into consideration, those species which were captured in large quantities during the period following spring, whilst their host plants dominated in phytocoenosis, were considered to be characteristic of the studied sites. On this basis, thirteen aphid species were included within the group of taxa characteristic for both research sites: P. humuli, P. testudinaceus, D. platanoidis, A. sambuci, R. padi, A. fabae, C. aegopodii, B. divaricatae, S. avenae, C. theobaldii, M. dirhodum, E. betulae, M. carnosum, and additionally $P$. juglandis for the roadside. As stated in previous research articles, many of these species were observed as being characteristic of various non-agricultural sites regarded as typical across the agricultural landscape of the Wielkopolska and Kujawy regions, such as mid-field thickets, roadsides, forest edges or boundaries (Wilkaniec 2000, 2001; Bennewicz et al. 2001; Wilkaniec et al. 2000, 2008; Bennewicz 2010). Their significance stems primarily from the common occurrence of these host plant habitats in phytocoenosis including: $P$. humuli - blackthorn and cherry plum, $P$. testudinaceus and $D$. platanoidis - maple trees, and A. fabae - euonymus, C. aegopodii and C. theobaldi-willow, E. betulae - birch, B. divaricatae - cherry plum, R. padi - black cherry and grass, S. avenae - grasses, and $M$. carnosum - nettle. Only P. juglandis, a taxon growing on walnut, was unusual for roadside sites in Wielkopolska as this tree rarely grows by the side of a road.

The unique position of $R$. padi in the caught material should be commented on. A large quantity of this specimen is captured in traps, mainly in autumn; from mid-September until the end of the growth season. The same phenomenon can be observed not only in the agricultural landscape but also in e.g. urban green spaces (Wilkaniec 2000, 2001; Wilkaniec et al. 2000, 2008, 2012). In terms of numbers in catches, two species also found growing in grasses and cereals, i.e. A. corni and S. avenae, can never be on par with $R$. padi, hence, it is difficult to explain this phenomenon purely in terms of the extensive availability of host plants in phytocoenosis.

The obtained results point to significant differences in the number of groups within the research years, which impacts a whole array of factors, both abiotic and biotic.
The best conditions for aphid development were during the first season of the research. This was primarily associated with favourable weather conditions, i.e. a warm and moderately humid season.

Our understanding of the impact of landscape composition on the biological fight with pests in horticultural crops is relatively small (Brown 2004; Eilers and Klein 2009; Dib et al. 2010; Thomson and Hoffmann 2010; Stutz and Entling 2011). The results of the presented research point to the fact that uncultivated habitats surrounding apple orchards provide a good location for a wealth of aphid fauna to develop. The issue of to what extent this potential nutrient base may be used by different groups of predatory and parasitic insects, which could regulate the number of orchard pests, requires further research.

The results of our studies can be used in assessing the biodiversity of this group of insects in refuge habitats. Aphids are important as pests of plants, and vectors of virus diseases.

\section{References}

Banaszak J. 2000. Effect of habitat heterogeneity on diversity and density of pollinating insects. p. 123-140. In: "Interchanges of Insects Between Agricultural and Surrounding Lanscapes" (B. Ekbom, M.E. Irwin, Y. Robert, eds.). Kluwer Academic Publishers Dordrecht, Sweden, 239 pp.

Bennewicz J., Kaczorowski G., Barczak T. 2001. Aphids in mid-field thickets in Lower Vistula Landscape Park. Journal of Plant Protection Research 41 (4): 348-362.

Bennewicz J. 2010. Aphids (Hemiptera: Aphididae) of midfield thickets in agricultural landscape catches in Moericke traps. Polish Journal of Entomology 79 (2): 139-163.

Bianchi F.J.J.A., Booij C.J.H., Tscharntke T. 2006. Sustainable pest regulation in agricultural landscapes: a review on landscape composition, biodiversity and natural pest control. Proceedings of the Royal Society B. Biological Science 273 (1595): 1715-1727.

Blackman R.L., Eastop V.F. 1994. Aphids on the World's Trees. An Identification and Information Guide. CAB International, Wallingford, UK, 986 pp.

Bońkowska T. 1970. The effect of shelterbelts on the distribution of Carabidae. Polish Journal of Ecology 18A (28): 559-569.

Brown M.W. 2004. Role of aphid predator guild in controlling spirea aphid populations on apple in West Virginia, USA. Biological Control 29 (2): 189-198.

Chaplin-Kramer R., O’Rourke M.E., Blitzer E.J., Kremen C. 2011. A meta-analysis of crop pest and natural enemy response to landscape complexity. Ecology Letters 14 (9): 922-932.

Dennis P., Fry G., Andersen A. 2000. The impact of field boundary habitats on the diversity and abundance of natural enemies in cereals. p. 195-214. In: "Interchanges of Insects Between Agricultural and Surrounding Landscapes" (B.S. Ekbom, M.E. Irwin, Y. Robert, eds.), Springer, New York, 239 pp.

Dib H., Simon S., Sauphanor B., Capwiez Y. 2010. The role of natural enemies on the population dynamics of the rosy apple aphid, Dysaphis plantaginea Passerini (Hemiptera: Aphididae) in organic apple orchards in south-eastern France. Biological Control 55 (2): 97-109. 
Dąbrowska-Prot E. 1991. The role of forest islands in the shaping of the structure and functioning of entomofauna in an agricultural landscape. Polish Journal of Ecology 39 (4): 481-591.

Durak R., Wojciechowski W. 2008. Structure and dynamics of aphids communities connected with trees inselected forest associations. Polish Journal of Entomology 77 (2): 79-92.

Eilers E.J., Klein A.M. 2009. Landscape context and management effects on an important inscet pest and its natural enemies in almond. Biological Control 51 (3): 388-394.

Gałecka B. 1992. Importance of forest island for inhabiting of agricultural landscape by coccinellids (Coccinellidae, Coleoptera). Polish Journal of Ecology 39 (4): 561-577.

Gardiner M.M., Landis D.A., Gratton C., DiFonzo C.D., O'Neal M., Chacon J.M., Wayo M.T., Schmidt N.P., Mueller E.E., Heimpel G.E. 2009. Landscape diversity enhances biological control of an introduced crop pest in the north-central USA. Ecological Applications 19 (1): 143-154.

Hutcheson K. 1970. A test for comparing diversities based on the Shannon formula. Journal of Theoretical Biology 29 (1): 151-154.

Lethmayer C. 1998. Occurrence of aphids in an agricultural area with sown weed strips. p. 601-608. In: "Aphids in Natural and Managed Ecosystems" (J.M. Nieto Nafría, A.F.G. Dixon, eds.). León, Universidad de Leon Secretariado de Publicaciones, Leon, Spain, 688 pp.

Marczewski E., Steinhaus H. 1959. O odległości systematycznej biotopów. [About taxonomic distance of biotops]. Zastosowania Matematyki 4: 195-203.

Martin E.A., Reineking B., Seo B., Steffan-Dewenter I. 2013. Natural enemy interactions constrain pest control in complex agricultural landscapes. Proceedings of the National Academy of Science of the United States of America 110 (14): 5534-5539.

Mennalled F.D., Gross K.L., Hammond M 2001. Weed aboveground and seedbank community responses to agricultural management systems. Ecological Application 11 (6): 1586-1601.

Östman O., Ekbom B., Bengtsson J. 2001. Landscape heterogeneity and farming practice influence biological control. Basic and Applied Ecology 2 (4): 365-371.

Piekarska-Boniecka H., Siatkowski I., Zyprych J. 2010. Comparison of the collecting of the parasitoids belonging to the Pimplina subfamily (Hymenoptera, Ichneumonidae). Polish Journal of Entomology 79 (3): 283-290.

Pielou E.C. 1966. Shanon's formula as a measure of specific diversity: its use and misuse. The American Naturalist 100 (914): 463-465.

Pickett S.T.A., Cadenasso M.L. 1995. Landscape ecology: spatial heterogeneity in ecological systems. Science 269 (5222): 331-334.

Roland J., Taylor P.D. 1997. Insect parasitoid species respond to forest structure at different spatial scales. Nature 386 : 710-713.

Sawoniewicz J. 1979. The effect of shrub layer on the occurrence of the Ichneumonidae (Hymenoptera) in pine stands on different sites. Memorabilia Zoologica 30: 89-130.

Shanon C.E., Weaver W. 1963. The Mathematical Theory of Communications. University of Illinois Press, Urbana, USA, $205 \mathrm{pp}$.
Simpson E.H. 1949. Measurement of diversity. Nature 163: 688-691.

Stutz S., Entling M.H. 2011. Effects of the landscape context on aphid-ant-predator interactions on cherry trees. Biological Control 57 (1): 37-43.

Taylor L.R., Robert Y. 1984. A Handbook for Aphid Identification. Rothamsted Experimental Station, Harpenden, UK, $171 \mathrm{pp}$.

Thies C., Tscharntke T. 1999. Landscape structure and biological control in agroecosystems. Science 285: 893-895.

Thies C., Steffan-Dewenter I., Tscharntke T. 2003. Effects of landscape context on herbivory and parasitism at different spatial scale. Oikos 101 (1): 18-25.

Thies C., Roschewitz I., Tscharntke T. 2005. The landscape context of cereal aphid-parasitoid interactions. Proceedings of the Royal Society B. Biological Sciences 272 (1559): 203-210.

Thomson L.J., Hoffmann A.A. 2010. Natural enemy responses and pest control: importance of local vegetation. Biological Control 52 (2): 160-166.

Tilman D., Cassman K.G., Matson P.A., Naylor R., Polasky S. 2002. Agricultural sustainability and intensive production practices. Nature 418: 671-677.

Tischendorf L., Fahring L. 2000. On the usage and measurement of landscape connectivity. Oikos 90 (1): 7-19.

Tscharnke T., Brandl R. 2004. Plant insect interactions in fragmented landscapes. Annual Review of Entomology 49: 405-430.

Tscharntke T., Bommarco R., Clough Y., Crist T.O., Kleijn D., Rand T.A., Tylianakis J.M., van Nouhuys S., Vidal S. 2007. Conservation biological control and enemy diversity on a landscape scale. Biological Control 43 (3): 294-309.

Twardowski J., Hurej M., Jaworska T. 2006. An effect of stripmanagement on carabid beetles on sugar-beet crop. Journal of Plant Protection Research 46 (1): 1-11.

Wilkaniec B. 2000. Seasonal numerical changes of aphids in uncultivated habitats of agricultural landscape in Wielkopolska. Journal of Plant Protection Research 40 (2): 122-131.

Wilkaniec B. 2001. Aphidofauna of midfield thickets. Aphids and Other Homopterous Insects 8: 301-313.

Wilkaniec B., Borowiak-Sobkowiak B., Piekarska-Boniecka H. 2008. Selected insect groups of shrubbery complexes of „Biedrusko" Protected Landscape. Part I: Aphids (Hemiptera: Aphidoidea). Polish Journal of Entomology 77 (2): 93-107.

Wilkaniec B., Lewandowski R., Borowiak-Sobkowiak B. 2012. The effectiveness of catching aphids (Hemiptera: Sternorrhyncha: Aphidinea) in Moericke and light traps. Journal of Plant Protection Research 52 (2): 252-256.

Wilkaniec B., Piekarska-Boniecka H., Suder A. 2000. Aphids (Homoptera, Aphidodea) of refuge habitats in the agricultural landscape of Wielkopolska. Aphids and Other Homopterous Insects 7: 117-124.

Wojciechowicz-Żytko E. 2009. Predatory syrphids (Diptera, Syrphidae) and ladybird beetles (Coleoptera, Coccinellidae) in the colonies of Aphis fabae Scopoli, 1963 (Hemiptera, Aphidoidea) on Philadelphus coronaries L. Aphids and Other Hemipterous Insects 15: 169-183.

Wojciechowicz-Żytko E., Wnuk A. 2009. The occurrence of Coccinellidae (Coleoptera) in Aphis fabae Scopoli, 1763 (Hemiptera, Aphidoidea) colonies on broad bean intercropped with phacelia. Aphids and Other Hemipterous Insects 15: 183-195. 